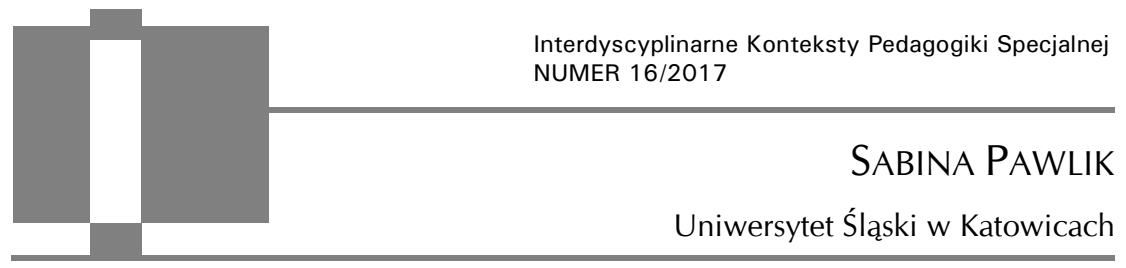

\title{
Twórczość artystyczna jako sposób urzeczywistniania paradygmatu emancypacyjnego
}

\begin{abstract}
Sabina Pawlik, Twórczość artystyczna jako sposób urzeczywistniania paradygmatu emancypacyjnego [Artistic creation as a way to realize the emancipatory paradigm]. Interdyscyplinarne Konteksty Pedagogiki Specjalnej, nr 16, Poznań 2017. Pp. 129-142. Adam Mickiewicz University Press. ISSN 2300-391X

The article relates to artistic creation of intellectually disabled people as an example of possible means of their emancipation. In this paper I claim that artistic creation of intellectually disabled people may constitute a tool of self-expression, and as a result be a way to realize the emancipatory paradigm in special education. I have illustrated my hypothesis with some poetry written by two women affected by Down syndrome whose creation is a conscious act of formulating an autonomous artistic message.
\end{abstract}

KEY WORDS: intellectual disability, artistic creation, emancipation, paradigms of special education

\section{Wprowadzenie}

Zmiany społeczno-kulturowe zachodzące we współczesnym świecie, w którym przekształceniom ulegają normy, wzorce i wartości, mają wpływ na myśl pedagogiki specjalnej, która podążając z nimi, sama ulega przeobrażeniom. Współczesne postrzeganie zjawiska niepełnosprawności dalekie jest od silnie dominującego w XX w. 
podejścia medycznego, a niepełnosprawność zaczyna być traktowana jako zespół czynników cechujących ludzką kondycję i poddawana jest refleksji społecznej i egzystencjalnej. Jolanta Rzeźnicka-Krupa zauważa, że definiowanie niepełnosprawności zmierza obecnie do rozważań nad trudnościami w zmaganiu się z ciężarem egzystencji w sytuacjach niepełnej sprawności oraz nad potencjałem, który jest udziałem każdej ludzkiej jednostki, niezależnie od jej dysfunkcji1 ${ }^{1}$. Według Iwony Chrzanowskiej, w efekcie zmian podejścia do niepełnosprawności i osób z niepełnosprawnością, jakie miały miejsce w ostatnich dekadach, „coraz wyraźniejsze jest dążenie środowisk osób z niepełnosprawnością do wypowiadania się w swoich sprawach" 2 .

W opracowaniu stawiam tezę, że twórczość artystyczna osób z niepełnosprawnością intelektualną jest sposobem wypowiadania się w swoich sprawach, a w konsekwencji sposobem, drogą urzeczywistniania paradygmatu emancypacyjnego w pedagogice specjalnej.

\section{Emancypacja osób z niepełnosprawnością intelektualną}

„Na kanwie dyskusji o podmiotowym traktowaniu człowieka niepełnosprawnego i uzyskaniu przez niego, niezależnie od posiadanej dysfunkcji, jak największej autonomii, pojawia się szersza perspektywa wyzwolenia go z ograniczeń roli, jaką mu społecznie przypisano"3 - zauważa Amadeusz Krause. Emancypacja, zgodnie z definicją Marii Czerepaniak-Walczak rozumiana jest jako proces „(...) zmieniania warunków funkcjonowania podmiotu i/albo zbiorowego, wprowadzania intencjonalnych zmian $\mathrm{w}$ podmiotowym świecie życia w celu przekraczania uwarunkowań aktualnej egzy-

${ }^{1}$ J. Rzeźnicka-Krupa, Komunikacja-edukacja-społeczeństwo. O dyskursie dzieci z niepetnosprawnością intelektualna, Oficyna Wydawnicza „Impuls”, Kraków 2007, s. 14.

2 I. Chrzanowska, Pedagogika specjalna. Od tradycji do współczesności, Oficyna Wydawnicza „Impuls”, Kraków 2015, s. 415.

${ }^{3}$ A. Krause, Wspótczesne paradygmaty pedagogiki specjalnej, Oficyna Wydawnicza „Impuls”, Kraków 2010, s. 106. 
stencji. Wyraża się w wypowiadaniu własnych sądów i opinii oraz podejmowaniu suwerennych decyzji w warunkach opresji i ograniczeń oraz w działaniu, którego celem jest zmienianie świata i siebie"4. W kontekście rozważań z zakresu pedagogiki specjalnej emancypacja to „zarówno indywidualne, jak i zbiorowe wyzwolenie osób niepełnosprawnych $\mathrm{z}$ dominacji pełnosprawności, $\mathrm{z}$ następstw, jakie ich dysfunkcja wywołuje w społeczeństwie, z utrudnień w funkcjonowaniu, jakie powoduje. Podstawą emancypacji jest nabywanie przez te osoby podmiotowości i autonomii, a na ich podstawie odzyskanie wolności, którą przez niepełnosprawność utraciły" 5 .

O ile emancypacja osób z niepełnosprawnością pozaintelektualną nie przysparza wielu wątpliwości, to emancypacja osób z niepełnosprawnością intelektualną, ze względu na przypisywaną podmiotowi niską świadomość i nieracjonalność, może wydawać się dyskusyjna ${ }^{6}$. Jednak, jak zauważa Krause, niezależnie od ograniczeń związanych z niepełnosprawnością, człowiek jest zdolny do osiągania kolejnych, możliwych dla niego poziomów emancypacji ${ }^{7}$. Według Beaty Cytowskiej pierwszym, koniecznym postulatem dla rozpoczęcia dyskusji na temat emancypacji osób z niepełnosprawnością intelektualną jest odejście od tradycyjnych, medycznych, rehabilitacyjnych i indywidualnych dyskursów w pedagogice specjalnej, a zwrócenie się ku podejściu humanistycznemu, w którym dużą wagę przywiązuje się do refleksji na temat wolności, podmiotowości i autonomii osób z niepełnosprawnością intelektualną. Autorka zauważa, że sprawą kluczową wydaje się być również edukacja i wychowanie do emancypacji, które swoim zasięgiem objąć ma nie tylko osoby z niepełnosprawnością intelektualną, ale również ich najbliższe otoczenie ${ }^{8}$.

${ }^{4}$ M. Czerepaniak-Walczak, Pedagogika emancypacyjna, GWP, Gdańsk 2006, s. 29.

${ }^{5}$ A. Krause, op. cit., s. 206.

${ }^{6}$ B. Cytowska, Trudne drogi adaptacji. Watki emancypacyjne w analizie sytuacji dorostych osób z niepetnosprawnością intelektualną we wspótczesnym społeczeństwie polskim, Oficyna Wydawnicza „Impuls”, Kraków 2012, s. 343.

7 A. Krause, op. cit., s. 206.

8 B. Cytowska, op. cit, s. 343. 


\section{Twórczość artystyczna jako jedna z możliwych dróg emancypacji}

"Coraz wyraźniejsze jest dążenie środowisk niepełnosprawnych
do wypowiadania się w swoich sprawach" - zauważa Iwona Chrzanowska9. Mówienie własnym głosem, we własnym imieniu, zwane inaczej rzecznictwem własnym, określa się jako „bezpośrednie występowanie $\mathrm{w}$ interesie własnym poszczególnych osób z niepełnosprawnością"10. Sytuacja osób z niepełnosprawnością intelektualną w tym zakresie wydaje się być szczególna, ponieważ uważane są za takie, które, „często nie potrafią tworzyć złożonych narracji i w akcie świadomej refleksji odnieść się do otaczającej je rzeczywistości i własnej egzystencji"11. Cytowana przez Chrzanowską Dorota Podgórska-Jachnik zaprzecza takiej tezie, wskazując, że większość osób z intelektualną niepełnosprawnością potrafi korzystać z prawa do wpływania na własne życie i mówienia o tym osobiście ${ }^{12}$. Kluczowe wydaje się odzyskanie utraconego na mocy społecznych i kulturowych doświadczeń prawa do uznania własnego głosu za głos znaczący oraz uznania mowy za społecznie ważną, w konsekwencji do bycia postrzeganym jako podmiot zdolny do formułowania autonomicznego przekazu13.

Miejscem „społecznej widzialności i słyszalności”14 osób z niepełnosprawnością intelektualną może być twórczość artystyczna

9 I. Chrzanowska, op. cit., s. 414.

10 Ibidem, s. 414, cyt za: D. Podgórska-Jachnik, Ruch self-adwokatów jako rozwijanie kompetencji rzecznictwa wtasnego osób z niepetnosprawnościa intelektualna, [w:] Problemy rzecznictwa i reprezentacji osób niepetnosprawnych, red. D. Podgórska-Jachnik, WSP, Łódź 2009, s. 180-182.

${ }^{11}$ J. Rzeźnicka-Krupa, Niepetnosprawność i świat społeczny. Szkice metodologiczne, Oficyna Wydawnicza „Impuls”, Kraków 2009, s. 221.

12 I. Chrzanowska, op. cit., s. 414, cyt za: D. Podgórska-Jachnik, op. cit., s. 180-182.

${ }^{13}$ E. Godlewska-Byliniak, J. Lipko-Konieczna, Publiczne-prywatne: teatralna gra z niepetnosprawnością, [w:] 21 myśli o teatrze, red. E. Godlewska-Byliniak, J. Lipko-Konieczna, Fundacja Win-Win, Warszawa 2016, s. 12.

14 Ibidem, s. 12. 
służąca jako element budujący ich tożsamość. W tomie Terapia i teatr. Wokót problematyki teatru ludzi niepetnosprawnych Rafał Zięba zauważa, że milczenie rozumiane jako odbieranie prawa głosu osobom $\mathrm{z}$ niepełnosprawnościami, jako konsekwencja tradycyjnego podejścia do ich problemów, zostało dobitnie przełamane właśnie na terenie twórczości artystycznej ${ }^{15}$. To ona daje osobom $\mathrm{z}$ niepełnosprawnością „możliwość przełamania utrwalonych postaw psychospołecznych izolujących ludzi niepełnosprawnych, możliwość wyzwolenia ich z poczucia alienacji, samotności i bezradności"16. Przekaz z niej płynący będzie formą „mówienia” własnym głosem, we własnym imieniu, jednak wyłącznie pod warunkiem, że będzie dana im szansa, aby treścią swojej twórczości uczynili świat własnych, osobistych doświadczeń, oraz że zostanie uszanowany ich swoisty, niepowtarzalny sposób wypowiedzi i odmienna interpretacja świata ${ }^{17}$.

Szczególnym przejawem twórczości artystycznej, w której istnieje możliwość kształtowania własnych wypowiedzi, jest twórczość literacka.

Nasuwa się pytanie o to, czy jest ona dostępna również osobom $\mathrm{z}$ niepełnosprawnością intelektualną?

Wiedzę o językowej sferze funkcjonowania tej grupy osób konstruują na ogół informacje „wskazujące na negatywne właściwości ich języka i mowy, pozostające w zależności z istniejącym deficytem intelektualnym"18. W literaturze naukowej często pojawia się twierdzenie dotyczące funkcjonowania sfery językowej osób z niepełnosprawnością intelektualną mówiące o tym, że jednostki te „mają trudność w wyrażaniu swoich myśli i rozumieniu wypowiedzi innych osób"19. Osoby z niepełnosprawnością intelektualną uchodzą

${ }^{15}$ R. Zięba, Milczenie ciała (szkic), [w:] Terapia i teatr. Wokół problematyki teatru ludzi niepetnosprawnych, red. I. Jajte-Lewkowicz, A. Piasecka, Poleski Ośrodek Sztuki, Łódź 2006, s. 30.

16 I. Jajte-Lewkowicz, Stowo wstepne, [w:] Terapia i teatr..., s. 7.

17 R. Zięba, op. cit., s. 30.

${ }^{18}$ D. Krzemińska, Język $i$ dyskurs codzienny osób z niepetnosprawnością intelektualna, Oficyna Wydawnicza „Impuls”, Kraków 2012, s. 9.

19 Tamże, s. 15, cyt. za: J. Sowa, Pedagogika specjalna w zarysie, FOSZE, Rzeszów 1997, s. 144. 
za niezdolne do stworzenia złożonych wypowiedzi i świadomej refleksji nad otaczającą je rzeczywistością i własną egzystencją ${ }^{20}$.

Jednak, jak zauważa Rzeźnicka-Krupa, najważniejsze bariery tkwią w niemożności przekonania nas samych (osób uważających się za sprawne) do tego, „iż osoby, których doświadczenia pojęciowe i komunikacyjne wydają się tak niepewne, „mają także swój wewnętrzny świat, oraz egzystują w przestrzeni określonych relacji międzyludzkich i społecznych"21.

Przeświadczenia dotyczące z jednej strony ubogich zdolności językowych osób z niepełnosprawnością intelektualną, z drugiej ich nieracjonalności i małej świadomości przełamują dwie kobiety Justyna Matysiak i Barbara Lityńska. Łączy je nie tylko to, że obydwie są kobietami z zespołem Downa. Obydwie są niezwykle twórczymi osobowościami, które potrafią pisać o swoim świecie w sposób niezwykle szczery i przejmujący.

\section{"Nina $100 \%$ kobieta" ${ }^{22}$}

Justyna Matysiak znana jest przede wszystkim jako autorka rysunków. Od 2000 r. jest uczestniczką Warsztatów Terapii Zajęciowej Krzemień w Poznaniu. W 2008 r. zaczęła tworzyć w Otwartej Pracowni Galerii Tak w Poznaniu. Jako jedyna Polka w 2007 r. otrzymała grand prix Insita, przyznane $\mathrm{w}$ ramach 8 . Triennale sztuki art brut/outsider art przez Słowacką Galerię Narodową w Bratysławie. Jej prace znajdują się $\mathrm{w}$ wielu międzynarodowych kolekcjach, m.in.: w Musée de la Création Franche w Bègles we Francji, Słowackiej Galerii Narodowej w Bratysławie, The Museum of Everything w Londynie, Muzeum Sztuki Współczesnej w Ołomuńcu, Państwowym Muzeum Etnograficznym w Warszawie, Muzeum

\footnotetext{
${ }^{20}$ J. Rzeźnicka-Krupa, Niepetnosprawność i świat spoteczny..., s. 221.

${ }^{21}$ Ibidem, s. 223.

${ }^{22}$ Tekst znajdujący się na jednym z rysunków Justyny Matysiak.
} 
Śląskim w Katowicach, Muzeum Etnograficznym w Krakowie i wielu kolekcjach prywatnych, m.in. Leszka Macaka w Krakowie ${ }^{23}$.

Elementem niezwykle fascynującym $\mathrm{w}$ twórczości artystki, pojawiającym się obok rysunku jest autoreferencyjny tekst ${ }^{24}$. Małgorzata Szaefer, opiekun artystyczny Matysiak, ale również osoba bardzo jej bliska, zauważa:

Jej ostanie obrazy są jak ogłoszenia matrymonialne: kobieta zachwala w nich swoje wdzięki i czeka, aż jakiś mężczyzna się nią zainteresuje [...] tworzy rysunki, które stanowią jej rozmowę z samą sobą [...]. Wie pani o czym ostatnio najchętniej pisze $\mathrm{w}$ swoich tekstach-obrazach? O tym, co zrobić mężowi na obiad. Coś co dla większości współczesnych kobiet wydaje się mało fascynujące, jej dałoby wolność ${ }^{25}$.

Szaefer zwraca uwagę, że małżeństwo jest dla Matysiak terytorium idealnym, nieosiągalnym dla niej samej.

\section{JA CHCIAEAM MIEĆ CHEOPAKA [...]/CHCIAEAM MIEĆ BARDZO DUŻO MIEOŚCI/ SZCZĘŚCIA RADOŚCI/RODZINA/JA CHCE BYĆ ŻONA PAWEEA/ŻONA MOJA SERCE MOJE/KOCHANE MOJE/KWIA- TECZKU/MIŚKU/SKARBIE MÓj26}

W katalogu wystawy „Nie jestem już psem”, prezentowanej w Muzeum Śląskim w Katowicach, w całości poświęconej twórczości outsiderów, kuratorki: Zofia Czartoryska oraz Katarzyna Kar-

${ }^{23}$ M. Szaefer, Ja cała czarna. Nie moge znaleźć chłopaka. Na znak czarne serce. Nie mam chłopaka, http://galeriatak.pion.pl/justyna-czarna/ [dostęp: 30.05.2017].

${ }^{24}$ Katalog online wystawy „Nie jestem już psem”. Muzeum Śląskie, 1.04-10.09. 2017, http:/ / niejestemjuzpsem.muzeumslaskie.pl/all/justyna-matysiak/ [dostęp: 30.05.2017].

${ }^{25}$ I. Meyza, Pokochaj mnie jak Pierre Cardin, [w:] Twarze sukcesu. Zespót Downa, Bardziej Kochani, Warszawa 2014.

26 Teksty Justyny Matysiak pochodzą z rysunków wystawionych w Muzeum Śląskim w Katowicach podczas wystawy „Nie jestem już psem”. Pisownia literami drukowanymi akcentuje odręczność tekstów Justyny Matysiak. Starałam się również o zachowanie oryginalnej składni i pisowni, chociaż ze względu na zrozumiałość przekazu nie zawsze było to możliwe. 
wańska zauważają, że ostatnie teksty Justyny coraz silniej wyrażają ból i sprzeciw wobec własnej sytuacji egzystencjalnej.

HISTORIA NINY/SMUTNA SAMOTNA/ZAEAMANA(...)JUSTYNA NIE CHCE KRZEMIENIA/WARSZTATY (...)/NIE NIE/NIE NIE

MUSZĘ WRÓCIĆ/ZDROWIA/ODPOCZNE SOBIE/LEŻE SOBIE NA KANAPIE/WYPIJĘ CIEPEA HERBATE/TELEWIZJE/OGLACDAM/GAZETE/ OGLAZDAM/I KAWA/CIEPEE SKARPETY/JESZCZE NIE JESTEM SZCZĘŚLIWA/ZAEAMANY/J.M.

HISTORIA/ JUSTYNY/KONIEC ZE MNA_NIE MOGĘ ZNALEŹĆ CHŁOPAKA/ZNAK CZAR/NEJ SERCE JUSTYNY/NA ZNAK CZARNEJ/ SERCA/J.M/JUSTYNY/NIE MAM/CHŁOPAKA/NIE MAM/CHŁOPAKA

Zwracają również uwagę, że w najnowszych pracach artystki pojawia się motyw buntu kobiety, konkludując, że „sztuka Matysiak jest sztuką feministyczną - walką o prawo do samodzielne-go kształtowania własnej kobiecości, własnego stylu, własnego życia”27.

JUSTYNA/CZARNY SERCE/CZARNE PROTEST/MÓJ CZARNY PROTEST/BEZ SERCA/BEZ SZCZĘŚCIA/BEZ MIEOŚCI/J.M

MÓJ JUSTYNY/CZARNY PROTEST/NIE CHCE JEZDZIĆ/KRZEMIENIA DO PRACY/DO ROBOTY/JA CHCE JEZDZIĆ NA GALERIA TAK/GOSIA SZEFER/CODZIENNIE (...)/JA CHCIAŁAM MIEĆ CHŁO$P A K A(\ldots) / J \cdot M$

Złożone, wielowątkowe teksty Matysiak odsłaniające jest stany emocjonalne, rządzą jej pracami. Jej narracje, jak zauważa Małgorzata Szaefer, są tekstem performatywnym, który na bieżąco odsłania stan ducha artystki ${ }^{28}$. Szaefer konkluduje:

Prace J.M. to sztuka tożsama z życiem na $100 \%$. Sztuka, która nie tyle używa rzeczywistości, co $\mathrm{w}$ pełni nią jest. Sztuka, która nie istnieje

${ }^{27}$ Katalog online wystawy „Nie jestem już psem”. Muzeum Śląskie, 1.04-10.09. 2017, http://niejestemjuzpsem.muzeumslaskie.pl/all/justyna-matysiak [dostęp: 30.05.2017].

${ }_{28}^{2}$ M. Szaefer, Ja cała czarna. Nie moge znaleźć chłopaka. Na znak czarne serce. Nie mam chłopaka, http://galeriatak.pion.pl/justyna-czarna [dostęp: 30.05.2017]. 
bez warstwy tekstowej, czy paratekstowej, bo tekst pełni tu rolę objaśniającą, stając się odsyłaczem i shifterem głosu Justyny Matysiak. Dla mnie to bezbronna, nie dofinansowana kampania na rzecz własnego szczęścia ${ }^{29}$.

\section{„Jestem taka jak ty, tylko inna"30}

Barbara Lityńska mieszka w Warszawie. Jest aktorką „Teatru 21", którego aktorami są osoby z Zespołem Downa i autyzmem. Na swoim koncie ma role w filmie dokumentalnym („Randez-vous” Marcina Janosa Krawczyka) i serialu („Głęboka woda”, reż. Magdalana Łazarkiewicz). Jest również autorką trzech tomików wierszy. Ostatni został wydany w 2016 r. Sama siebie uważa za poetkę, „nie jakąś wielką, ale malutką" 31 . Wiersze Lityńskiej "są proste i krystalicznie przejrzyste, bez udawania, zbędnych formalnych fiołków" zauważa Sylwia Szwed w reportażu o autorce zamieszczonym w książce Twarze sukcesu. Zespół Downa ${ }^{32}$. Cechą charakterystyczną jej poezji jest prostota i bezpośredniość wyrazu. W swoich wierszach nazywa uczucia i emocje, których doświadcza w relacjach z najbliższymi: mamą, siostrą, asystentką, reżyserką teatralną33.

$* * *$

moja mama pracuje nawet $\mathrm{w}$ domu/to jest ciężkie/ i się odbija na mnie/ciągle jest zmęczona/bez przerwy muszę znosić jej humory/a jak ją błagam/żeby przestała pracować/to się na mnie wydziera ${ }^{34}$

29 Ibidem.

${ }^{30}$ Fragment wiersza Barbary Lityńskiej cytowany za: S. Szweda, Taka jak ty, tylko inna, [w:] Twarze sukcesu..., s. 43.

31 Ibidem, s. 42.

32 Ibidem.

33 Interpretacji poezji Lityńskiej podjął się na swoim kanale na YouTube wydawca jej poezji, Franek Wygoda (Franek L. Vigoda), https://www.youtube.com/ watch?v=dDgoRJzGnoo [dostęp: 30.05.2017], w opracowaniu korzystam z jego interpretacyjnych wskazówek.

${ }^{34}$ Wiersze pochodzą z tomiku Barbary Lityńskiej: B. Lityńska, Wiersze nowe, VigodaPress, Warszawa 2016. 


\section{Wyjazdy Olgi}

jestem smutna bo Olga/często wyjeżdża z domu/jest mi nieprzyjemnie, bo tęsknię za nią/lubię ją/lubię, jak opowiada śmieszne kawały/lubię jak się uśmiecha

Ważnym tematem poezji Lityńskiej jest opowieść o inności i niepełnosprawności. Zespół Downa w jej wierszach traktowany jest jako choroba; na przeciwległym krańcu, według poetki, znajduje się zdrowie. Poezja jest próbą konfrontowania się ze światem ludzi zdrowych, jest to rodzaj trampoliny między tymi dwoma światami ${ }^{35}$. Wiersze są świadectwem poszukiwania swojego miejsca w społeczeństwie, w którym Lityńska początkowo, aby przetrwać, zakładała różne maski. Po pewnym czasie, jak pisze w swoim wierszu, zdecydowała się je zdjąć. Chce żyć wśród ludzi „normalnie”, bez taryfy ulgowej przysługującej osobom z niepełnosprawnością intelektualną.

\section{Maski}

zakładam maski/za którymi ukrywałam strach/przed swoją chorobą/(...)/ a przecież chodzi o to, żeby wyjść naprzeciw siebie i lu$\mathrm{dzi} /$ wiem, że z tą chorobą można wspaniale żyć36

ja mam chorobę/która nazywa się zespół Downa/z tą choroba można wiele osiągnąć/wiele się nauczyć/jestem w stanie być osobą/zupełnie zdrową/jeśli się nauczę matematyki

W wierszach Barbary Lityńskiej, podobnie jak w tekstach Justyny Matysiak, odkryć można motywy buntu, niezgody na swój los. Poetka wyraża swój protest przeciwko sytuacji wykluczenia, w jakiej się znajduje jako osoba z niepełnosprawnością.

35 S. Szweda, op. cit. s. 43.

36 Wiersz cytowany jest za: ibidem, s. 42. 
$* * *$

jestem jak ryba w morzu, porzucona i samotna/nie wiem, co mam robić/szukam brzegu/gdzie mogę odpocząć/i pomarzyć o życiu zawodowym/to moje szczęście/że zarabiam pieniądze

\section{Samodzielność}

jestem dorosła/mam samodzielne życie/mam prawo myśleć/inaczej niż inni/nikt mi tego prawa nie odbierze/mam prawo cieszyć się życiem i układać je jak chcę

Nie brak w jej poezji również akcentów pozytywnych. Autorka posiadła wielką sztukę i mądrość odnajdywania radości w codziennych rzeczach i sytuacjach ${ }^{37}$. Znajdziemy w wierszach ślady jej wiary we własne możliwości i determinacji do zmiany swojego losu na lepszy.

***

Uwielbiam swoje serce/które podpowiada mi dobre rozwiązania/i dobre decyzje/jestem odważna rozsądna i mądra/inteligentna/za taką się uważam/ja mam własne pomysły na swoje życie/nikt nie będzie mi mówił/jak mam żyć

Barbara Lityńska w swojej poezji w sposób spontaniczny wyraża stany i uczucia, które odczuwamy my wszyscy, choć nie potrafimy lub nie chcemy się do tego przyznać. Daje świadectwo, że również osoby $\mathrm{z}$ niepełnosprawnością intelektualną są zdolne do „sensownego ujmowania rzeczywistości oraz nadawania jej osadzonych w naszym rozumieniu - a więc «właściwych i odpowiednich» - znaczeń ${ }^{38}$.

Poezja Lityńskiej jest swoistym manifestem, a każdy jej wers woła o normalność i równe traktowanie ${ }^{39}$.

37 Interpretacyjna wskazówka Franka Wygody na kanale YouTube, https://www. youtube.com/watch?v=dDgoRJzGnoo [dostęp: 30.05.2017].

38 J. Rzeźnicka-Krupa, Niepetnosprawność i świat społeczny..., s. 223.

39 S. Szweda, op. cit., s. 42. 


\section{Czy mnie zaakceptujesz?}

[...] przyjmij to do wiadomości, że ja inna nie będę/albo mnie zaakceptujesz/albo tobie będzie ciężko ze mnąa

Pytanie „czy mnie zaakceptujesz?”, jest pytaniem rzuconym do czytelnika, trafiającym w sedno problemu. Z tym pytaniem każdy odbiorca pozostaje sam, i sam powinien na nie odpowiedzieć.

\section{Na zakończenie}

Osoby z niepełnosprawnością intelektualną, podobnie jak inni członkowie społeczeństwa, mają prawo do własnych wypowiedzi i są w stanie brać udział w procesach społecznych i życiu codziennym. Nie można zatem odmawiać im równego prawa do wyrażania osobistych znaczeń, również poprzez twórczość literacką. „Słowa wypowiedziane lub zapisane są symbolem i obrazem czegoś-interpretacją, są widzeniem świata. Mają moc kreacyjną również wtedy, gdy ich autorem jest osoba z lżejszą czy głębszą niepełnosprawnością intelektualną" - zauważa Beata Borowska-Beszta ${ }^{41}$.

Poezja osób z niepełnosprawnością intelektualną daje czytelnikowi szanse wsłuchania się w ich głos. Fakt, iż przytoczone teksty wyszły spod pióra twórczyń z niepełnosprawnością intelektualną, pozwala sądzić, jak trafnie spostrzega Dorota Krzemińska „że istnieje jedność odczuć i emocji wobec życia, śmierci, miłości, cierpienia, radości, wiary w Boga, spraw błahych, codziennych"42. Dzięki niej możemy dowiedzieć się, jak i czym żyją osoby z niepełnosprawnością intelektualną, w jaki sposób konstruują swój świat oraz jakie znaczenia przypisują sobie i doświadczanej rzeczywistości ${ }^{43}$.

40 Wiersz cytowany jest za: ibidem.

41 B. Borowska-Beszta, Echa ekspresji. Kulturoterapia w andragogice specjalnej, Oficyna Wydawnicza „Impuls”, Kraków 2008, s. 104.

42 D. Krzemińska, Język $i$ dyskurs codzienny osób z niepetnosprawnościa intelektualną, Oficyna Wydawnicza „Impuls”, Kraków 2012, s. 12.

43 Ibidem, s. 10. 
Ukazane przykłady odsłoniły, że sensy nie są ukryte w złożonych i zawiłych zdaniach, ale zawierają się w wypowiedziach szczerych i bezpośrednich, niezależnie od stopnia ich złożoności. Niosą one ze sobą bogactwo znaczeń i ogromny ładunek wiedzy o świecie autorek. „Czytelnik, który popatrzy na te prace przez pryzmat poprawności gramatycznej i ortograficznej nigdy nie zrozumie wysiłku włożonego przez osoby niepełnosprawne w ich napisanie, jak również prawdy przekazu ich myśli czy uczućt4" - zauważa Borowska-Beszta.

Jeśli osoby z niepełnosprawnością intelektualną uznamy za podmioty zdolne formułować autonomiczny przekaz artystyczny, wówczas pole sztuki stanie się miejscem ich społecznej widzialności i słyszalności, a w konsekwencji urzeczywistnianiem się paradygmatu emancypacyjnego w pedagogice specjalnej. Osoby z niepełnosprawnością zyskują wówczas „prawo do uznania własnej mowy za społecznie ważną", a przekaz wychodzi poza ramy tego, co tylko estetyczne, a staje się przekazem politycznym ${ }^{45}$. Sztuka natchniona doświadczeniem niepełnosprawności staje się powrotem do własnej tożsamości, logiki i prawdy jej twórców.

\section{Bibliografia}

Borowska-Beszta B., Echa ekspresji. Kulturoterapia w andragogice specjalnej, Oficyna Wydawnicza „Impuls”, Kraków 2008.

Chrzanowska I., Pedagogika specjalna. Od tradycji do wspótczesności, Oficyna Wydawnicza „Impuls”, Kraków 2015.

Cytowska B., Trudne drogi adaptacji. Watki emancypacyjne w analizie sytuacji dorostych osób z niepetnosprawnościa intelektualna we wspótczesnym społeczeństwie polskim, Oficyna Wydawnicza „Impuls”, Kraków 2012.

Czerepaniak-Walczak M., Pedagogika emancypacyjna, GWP, Gdańsk 2006.

Godlewska-Byliniak E., Lipko-Konieczna J., Publiczne-prywatne: teatralna gra z niepetnosprawnością, [w:] 21 myśli o teatrze, red. E. Godlewska-Byliniak, J. Lipko-Konieczna, Fundacja Win-Win, Warszawa 2016.

44 B. Borowska-Beszta, op. cit., s. 108.

45 E. Godlewska-Byliniak, J. Lipko-Konieczna, op. cit., s. 12. 
Krause A., Wspótczesne paradygmaty pedagogiki specjalnej, Oficyna Wydawnicza „Impuls", Kraków 2010.

Krzemińska D., Jezzyk i dyskurs codzienny osób z niepetnosprawnościa intelektualną, Oficyna Wydawnicza „Impuls”, Kraków 2012.

Lityńska B., Wiersze nowe, VigodaPress, Warszawa 2016.

Meyza I., Pokochaj mnie jak Pierre Cardin, [w:] Twarze sukcesu. Zespót Downa, Bardziej Kochani, Warszawa 2014.

Rzeźnicka-Krupa J., Komunikacja - edukacja - społeczeństwo. O dyskursie dzieci z niepetnosprawnościa intelektualna, Oficyna Wydawnicza „Impuls”, Kraków 2007.

Rzeźnicka-Krupa J., Niepetnosprawność i świat społeczny. Szkice metodologiczne, Oficyna Wydawnicza „Impuls”, Kraków 2009.

Szaefer M., Ja cała czarna. Nie moge znaleźć chtopaka. Na znak czarne serce. Nie mam chtopaka, http://galeriatak.pion.pl/justyna-czarna [dostęp: 30.05.2017].

Szweda S., Taka jak ty, tylko inna, [w:] Twarze sukcesu. Zespót Downa, Bardziej Kochani, Warszawa 2014.

Terapia $i$ teatr. Wokót problematyki teatru ludzi niepetnosprawnych, red. I. Jajte-Lewkowicz, A. Piasecka, Poleski Ośrodek Sztuki, Łódź 2006.

Zięba R., Milczenie ciała (szkic), [w:] Terapia $i$ teatr. Wokót problematyki teatru ludzi niepetnosprawnych, red. I. Jajte-Lewkowicz (red.), Poleski Ośrodek Sztuki, Łódź 1999.

Netografia

https://www.youtube.com/watch?v=dDgoRJzGnoo [dostęp: 30.05, 2017].

http://niejestemjuzpsem.muzeumslaskie.pl/all/justyna-matysiak [dostęp: 30.05.2017].

http://galeriatak.pion.pl/justyna-czarna [dostęp: 30.05.2017]. 